\title{
Failure of Glucagon Release in Infants of Diabetic Mothers
}

\author{
S. R. BLOOM, D. I. JOHNSTON
}

British Medical fournal, 1972, 4, 453-454

\section{Summary}

Two hours after birth 30 normal infants had a fall in blood glucose of $20.6 \mathrm{mg} / 100 \mathrm{ml}$ and a rise of plasma pancreatic glucagon of $50.7 \mathrm{pg} / \mathrm{ml}$. Fifteen infants of diabetic mothers treated with insulin had a much greater fall in blood glucose of $77.5 \mathrm{mg} / 100 \mathrm{ml}$ and a smaller rise of glucagon of $20.9 \mathrm{pg} / \mathrm{ml}$. By comparison 14 small-for-dates infants, who are also prone to hypoglycaemia, had a blood glucose fall of $32.8 \mathrm{mg} / 100 \mathrm{ml}$ and a larger rise of pancreatic glucagon of $96.0 \mathrm{pg} / \mathrm{ml}$. It is suggested that the impaired pancreatic glucagon rise in the infants of diabetic mothers may be a significant factor in their hypoglycaemia.

\section{Introduction}

About half of the infants born to insulin-treated diabetic mothers have blood glucose levels below $20 \mathrm{mg} / 100 \mathrm{ml}$ in the first hours of life (Pildes, Forbes, O'Connor, and Cornblath, 1967; Farquhar and Isles, 1968). When this hypoglycaemia is associated with symptoms there is a significant incidence of brain damage on follow-up examination (Beard et al., 1971). Relative hyperinsulinism has been generally accepted as the most probable explanation of this hypoglycaemia but the evidence is conflicting (Adam, 1971).

Although these infants have adequate reserves of hepatic glycogen (Cornblath et al., 1961) and adipose tissue, there appears to be a failure of glucose mobilization. The hormone glucagon stimulates glycogenolysis and gluconeogenesis (Park and Exton, 1972) and may be an important influence in preventing hypoglycaemia. Its part in the period after birth, particularly in the infant of a diabetic mother, is therefore of great interest. Hitherto, lack of specificity and sensitivity in the glucagon radioimmunoassay has prevented its measurement in neonatal plasma.

\section{Patients and Methods}

Three groups of infants were studied: 30 were normal (gestation 37-41 weeks), 22 were infants of diabetic mothers (gestation 36-38 weeks), and 14 were below the 10th percentile in weight (Tanner and Thomson, 1970) (gestation 36-41 weeks). Fifteen of the diabetic mothers required insulin therapy in pregnancy and seven did not. Maternal consent for the venepunctures was obtained. At delivery, blood was collected from a maternal antecubital vein and as rapidly as possible from the vein of a doubleclamped segment of the umbilical cord. Two hours after birth a single sample was taken from a peripheral vein of the infant before the first feed. Neonates who are regarded as liable to hypoglycaemia have a routine blood glucose estimation at this time.

A 1-ml sample of blood for pancreatic glucagon measurement was collected into chilled heparinized tubes containing 1,000 kallikrein inactivating units aprotinin. It was immediately

Institute of Clinical Research, The Middlesex Hospital, London W.1 S. R. BLOOM, M.R.C.P., Medical Unit Registrar

Department of Child Health, King's College Hospital, London S.E.5 D. I. JOHNSTON, M.R.C.P., Research Fellow

centrifuged and the plasma was deep frozen within 15 minutes of venepuncture. Glucagon was measured by a radioimmunoassay (Bloom, 1971) using an antibody relatively specific for pancreatic glucagon. Samples from each group of infants were also measured using an antiserum from Dr. Unger's laboratory (30K) (Müller, Faloona, and Unger, 1971) and this gave identical results. The assay could routinely detect differences of $25 \mathrm{pg} / \mathrm{ml}$ between plasma samples with $95 \%$ confidence. Glucose was measured by a glucose oxidase method (Marks. 1959).

\section{Results}

As is shown in the Chart the mean rise of pancreatic glucagon in the two hours after birth in normal infants is $50.7 \mathrm{pg}$ and this is significantly greater $(P<0.01)$ than the rise in infants of diabetic mothers, whether insulin dependent or not. The plasma

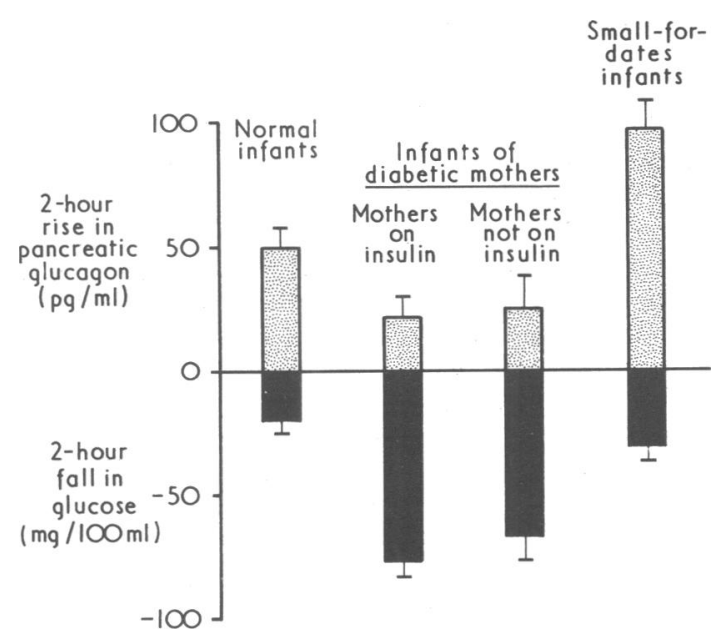

The rise in plasma glucagon and fall in blood glucose in the first two hours after birth. The bars indicate S.E. of mean.

Clinical Data on Patients in Study (S.E.s of Mean are given in parentheses)

\begin{tabular}{|c|c|c|c|c|c|}
\hline & & $\begin{array}{l}\text { Normal } \\
\text { Infants }\end{array}$ & $\begin{array}{l}\text { Infants of } \\
\text { Insulin- } \\
\text { Treated } \\
\text { Diabetic } \\
\text { Mothers }\end{array}$ & $\begin{array}{c}\text { Infants of } \\
\text { Non-insulin- } \\
\text { treated } \\
\text { Diabetic } \\
\text { Mothers }\end{array}$ & $\begin{array}{c}\text { Small-for- } \\
\text { dates } \\
\text { Infants }\end{array}$ \\
\hline \multicolumn{2}{|c|}{$\begin{array}{lll}\text { No. of infants } \quad \ldots \quad \ldots\end{array}$} & 30 & 15 & 7 & 14 \\
\hline \multicolumn{2}{|c|}{ Gestation in weeks $\quad$. } & $37-41$ & $36-38$ & $36-38$ & $36-41$ \\
\hline \multirow{2}{*}{\multicolumn{2}{|c|}{$\begin{array}{l}\text { Mean birth weight (g) .. } \\
\text { No. below } 10 \text { th percentile } \\
\text { for weight } \quad . .\end{array}$}} & $3,400(50 \cdot 0)$ & $3,240(160 \cdot 0)$ & $3,520(190 \cdot 0)$ & $2,310(50 \cdot 0)$ \\
\hline & & 0 & 2 & $\mathbf{0}$ & 14 \\
\hline $\begin{array}{l}\text { Maternal } \\
\text { levels at } \\
\text { delivery }\end{array}$ & $\left\{\begin{array}{l}\text { Glucagon } \\
\text { (pg/ml plasma }) \\
\text { Glucose } \\
(\mathrm{mg} / 100 \mathrm{ml} \text { blood })\end{array}\right.$ & $\begin{array}{l}124 \cdot 6(12 \cdot 3) \\
100 \cdot 5(3.6)\end{array}$ & $\begin{array}{l}129 \cdot 7(12.1) \\
144 \cdot 1(4 \cdot 0)\end{array}$ & $\begin{array}{l}125 \cdot 0(17 \cdot 3) \\
128 \cdot 3(9 \cdot 0)\end{array}$ & $\begin{array}{r}131 \cdot 4(8 \cdot 2) \\
96 \cdot 2(3 \cdot 2)\end{array}$ \\
\hline $\begin{array}{l}\text { Umbilical } \\
\text { vein levels } \\
\text { at delivery }\end{array}$ & $\left\{\begin{array}{l}\text { Glucagon } \\
\text { (pg/ml plasma) } \\
\text { Glucose } \\
(\mathrm{mg} / 100 \mathrm{ml} \text { blood })\end{array}\right.$ & $\begin{array}{r}138 \cdot 7(13 \cdot 7) \\
78 \cdot 2(4 \cdot 0)\end{array}$ & $\begin{array}{l}139 \cdot 1(13 \cdot 0) \\
110 \cdot 1(3 \cdot 2)\end{array}$ & $\begin{array}{l}125.0(23.3) \\
107.9(8.9)\end{array}$ & $\begin{array}{r}143 \cdot 6(14 \cdot 6) \\
76 \cdot 7(3 \cdot 2)\end{array}$ \\
\hline $\begin{array}{l}\text { Infant } \\
\text { peripherai } \\
\text { vein levels } \\
\text { at } 2 \mathrm{hr} \text {. }\end{array}$ & $\left\{\begin{array}{l}\text { Glucagon } \\
\text { (pg/ml plasma }) \\
\text { Glucose } \\
(\mathrm{mg} / 100 \mathrm{ml} \text { blood })\end{array}\right.$ & $\begin{array}{r}189 \cdot 4(14 \cdot 3) \\
57 \cdot 6(2 \cdot 2)\end{array}$ & $\begin{array}{r}160 \cdot 0(18 \cdot 3) \\
32.5(4 \cdot 7)\end{array}$ & $\begin{array}{c}148 \cdot 3(28 \cdot 1) \\
38 \cdot 8(4 \cdot 1\end{array}$ & $\begin{array}{c}239.6(18.2) \\
43.9(4.9)\end{array}$ \\
\hline \multicolumn{2}{|c|}{$\begin{array}{l}\text { No. with blood glucose } \\
\text { below } 20 \mathrm{mg} / 100 \mathrm{ml}\end{array}$} & 0 & 5 & $\mathbf{0}$ & 2 \\
\hline \multicolumn{2}{|c|}{$\begin{array}{l}\text { Pancreatic glucagon rise in } \\
2 \mathrm{hr}(\mathrm{pg} ! \mathrm{ml})\end{array}$} & $50 \cdot 7(7 \cdot 6)$ & $20.9(7 \cdot 8)$ & $23.3(13 \cdot 7)$ & $96 \cdot 0(12 \cdot 0)$ \\
\hline \multicolumn{2}{|c|}{$\begin{array}{l}\text { Significance level of } 2-\mathrm{hr} \\
\text { glucagon rise } \ldots\end{array}$} & $P<0.01$ & N.S. & N.S. & $P<0.001$ \\
\hline
\end{tabular}

N.S. $=$ Not significant. 
glucagon in small-for-dates infants rose significantly more than in the normal infants $(P<0.01)$. The infants of diabetic mothers, however, had the largest fall in blood glucose, reaching the lowest mean absolute level (see Table). The five infants of diabetics who developed a blood glucose below $20 \mathrm{mg} / 100 \mathrm{ml}$ had a mean pancreatic glucagon of $144.0 \mathrm{pg} / \mathrm{ml}$ at birth, and this rose only $16.0 \mathrm{pg}$ at two hours which was not significantly different from the group as a whole. The mean umbilical vein pancreatic glucagon level in six normal infants delivered by caesarean section was 128.3 (S.E. of mean 19.4), and in 10 infants of insulin-dependent diabetic mothers the mean level was 136.0 (S.E. of mean 19.6). These values do not differ significantly from each other or from the group as a whole.

\section{Discussion}

The conventionally accepted reason for hypoglycaemia in the neonate of a diabetic mother is excessive insulin release (Pedersen, Bojsen-Moller, and Poulsen, 1954; Baird, 1969). Insulin levels immediately after birth are certainly raised but so is the blood sugar. There is much controversy as to whether the insulin level is still inappropriately high during hypoglycaemia. Several workers have also reported that insulin release in the infants of diabetic mothers is not increased after intravenous glucose loads, nor is the glucose assimilation excessive (Isles and Farquhar, 1967; King, Adam, Clementi, and Schwartz, 1969). Therefore it is possible that hypoglycaemia is due in part or even primarily to a failure of glycogenolysis or gluconeogenesis.

The development of a sensitive microassay for pancreatic glucagon allows examination of a factor which may be of importance in this situation. Blood glucose in the infant of a diabetic has reached a nadir at about one hour after birth and then remains low for around six hours before gradually rising to more normal levels (McCann et al., 1966). The two-hour sampling time used in this study therefore encompasses the the period of maximum stimulus to glucagon release. Small-fordates infants were used as a comparison group. In general these infants develop hypoglycaemia as a consequence of nutritional depletion, and might therefore be expected to have normal hormonal responses. In fact they had a larger glucagon rise than the normal infants.
The blunted pancreatic glucagon response to severe hypoglycaemia in infants of diabetics could be explained in the following ways. Firstly, the pancreatic alpha cells of both normal neonates and the offspring of diabetic mothers may not be responsive to changes in blood glucose but controlled by other factors which are more identical. It has certainly been established that the normal neonatal beta cell has an impaired insulin response to glucose infusions (Isles, Dickson, and Farquhar, 1968). Secondly, it is possible that the alpha cell is affected by the prolonged intrauterine hyperglycaemia.

The cause of the hypoglycaemia after birth in an infant of a diabetic mother may well be multifactorial. The impairment of glucagon release is likely to be a significant component.

We would like to thank Dr. J. D. N. Nabarro and Professor C. E. Stroud for their helpful advice and manuscript corrections. Hoechst Pharmaceuticals Ltd. very kindly supplied antiserum $30 \mathrm{~K}$. This article is based on a paper delivered at the British Diabetic Association meeting in April 1972.

S.R.B. received support from the British Diabetic Association and D.I.J. was on a Maws Fellowship.

Requests for reprints should be addressed to: Dr. S. R. Bloom, Institute of Clinical Research, The Middlesex Hospital, London W.1.

\section{References}

Adam, P. A. J. (1971). Advances in Metabolic Disorders, 5, 183.

Baird, J. D. (1969). Fournal of Endocrinology, 44, 139.

Beard, A., et al. (1971). Fournal of Pediatrics, 79, 314.

Bloom, S. R. (1971). Diabetologia, 7, 472.

Cornblath, M., et al. (1961). Pediatrics, 28, 592.

Farquhar, J. W., and Isles, T. E. (1968). South African Medical fournal 42237.

Isles, T. W., Dickson, M., and Farquhar, J. W. (1968). Pediatric Research, Isles, T. E., and Farquhar, J. W. (1967). Pediatric Research, 1, 119.

King, K. C., Adam, P. A., Clementi, G. A., and Schwartz, R. (1969). Marks, V (1959), Clinica

Mcta, 4, 395.

. New England fournal of Medicine, 275, 1.

Faloona, G. R., and Unger, R. H. (1971). Fournal of Clinical Investigation, 50, 1992

Park, C. R., and Exton, J. H. (1972). In Glucagon, ed. P. J. Lefebre and R. H. Unger, p. 77. Oxford, Pergamon.

Pedersen, J., Bojsen-Moller, B., and Poulsen, H. (1954). Acta Endocrinologica' Kobenhavn), 15, 22 ,

Pildes, R., Forbes, A. E., O'Connor, S. M., and Cornblath, M. (1967) Fournal of Pediatrics, 70, 76.

Tanner, J. M., and Thomson, A. M. (1970). Archives of Disease in Childhood, $45,566$.

\title{
Haemostatic Changes during Dialysis Associated with Thrombus Formation on Dialysis Membranes
}

\author{
R. M. LINDSAY \\ C. R. M. PRENTICE, \\ J. F. DAVIDSON, \\ J. A. BURTON, \\ G. P. MCNICOL
}

British Medical fournal, 1972, 4, 454-458

\section{Summary}

Platelet counts, coagulation factors, and the fibrinolytic system were studied in seven regular dialysis patients

\footnotetext{
University Department of Medicine and the Department of Haematology, Royal Infirmary, Glasgow

R. M. LINDSAY, M.B., M.R.C.P., Senior Registrar in Medicine

C. R. M. PRENTICE, M.D., M.R.C.P., Senior Wellcome Research Fellow

J. F. DAVIDSON, M.B., M.R.C.P., Consultant Haematologist

J. A. BURTON, M.B., M.R.C.P., Senior Registrar in Medicine

University of Leeds

G. P. MCNICOL, M.D., F.R.C.P., Professor of Medicine (Present Address: Department of Medicine, General Infirmary, Leeds)
}

during the course of haemodialysis by parallel flow (Gambro-Alwall) and coil (Travenol Ultra-Flo 100) dialysers. Significant falls in the patients' platelet counts and rises in their factor $V$ levels were found with both dialysis systems. The changes were more pronounced over the course of a Gambro-Alwall dialysis, when significant falls in the partial thromboplastin clotting time and in the plasminogen levels were also noted. These haemostatic changes were associated with the retention of platelets on the dialysis membranes and, in the case of the Gambro-Alwall dialyser, with the formation of plateletfibrin thrombus. This thrombus formation may take place in spite of efficient heparin anticoagulation and may cause excessive blood loss to the regular dialysis patient. 